\title{
ASSESSING THE ENVIRONMENTAL IMPACTS OF INFORMAL SETTLEMENTS IN VIETNAM: THE CASE STUDY OF THE HUE CITADEL UNESCO WORLD HERITAGE SITE
}

\author{
BRONTE NIXON \\ WSP Australia Ltd and the University of South Australia, Australia
}

\begin{abstract}
Environmental Impact Assessment (EIA), although necessarily focussing on the negative impacts of projects, plans or policies, can also be a tool for quickly assessing impacts and prioritising environmental actions. Nowhere is this more effective than in the grassroots context of informal settlements. Worldwide, the number of people living in informal settlements is increasing, including in the rapidly urbanising countries of south-east Asia. The informal settlement at Hue Citadel, Vietnam, a UNESCO World Heritage site, grew during the American War in Vietnam in response to displacement and the need for protection from warfare. Temporary accommodation sprung-up behind the historical fortified ramparts and moat and is often the case with informal settlements, once temporarily established it flourished. The informal settlement now comprises hundreds of combined residential and business dwellings. Without adequate access to clean water, waste management or sanitation, coupled with a lack of infrastructure, the Hue informal settlement has impacted upon the surrounding environment. A resettlement plan has now been implemented by the government which will see residents relocated several kilometres away from the Citadel. Using the Citadel as a case study, this paper considers whether formal EIA could be adapted to rapidly assess the environmental impacts of informal settlements. Based upon the outcomes of this adaptive form of EIA, socio-economic surveys and available scientific literature, consideration could be given as to whether the implementation of an environmental improvement plan might allow people to remain living in an area within which they have strong social and cultural capital. Keywords: environmental improvement, hue citadel informal settlement, rapid EIA, relocation for conservation, world heritage
\end{abstract}

\section{INTRODUCTION}

Environmental Impact Assessment (EIA) is a tricky business. Whilst it has been established in 'western' countries for many years; in some 'developing' countries, it is a concept that has only recently been adopted. EIA is a formalised environmental management tool aiding environmental assessment and decision-making. As such, it provides an excellent framework for prioritising environmental studies and for determining the impacts of a development upon the receiving social and biophysical environment. Within this context, this paper investigates the complexities involved with assessing the environmental impacts of the informal settlement that has been established for many years within the Hue Citadel UNESCO (United Nations Educational, Scientific and Cultural Organisation) World Heritage Site in Vietnam. Hue Citadel was granted world heritage status in 1993 leading to a complex situation of land use conflict, restrictive management and ultimately; the displacement of a lively and connected community. This paper reviews the environmental issues at the World Heritage site by implementing a rapid or adaptive form of EIA, and subsequently determines whether the outcomes suggest that there could alternatively be an opportunity for people to remain living in their community. 


\section{BACKGROUND}

\subsection{Informal Settlements}

The UN-HABITAT estimates that worldwide; one billion people live in informal settlements (or slums), which includes $43 \%$ of the total urban population in developing countries [1,2]. Informal settlements do not only comprise a significant quantity of housing stock in cities; they are also growing more rapidly than the cities themselves [1]. The result can be an overcrowded city core with dense but extensive informal settlements on the periphery. Supporting this problem is often an ineffective planning system, the control of land development by the private sector or a single-party government, the focus of construction on expensive housing, and zoning and subdivision controls that ultimately exclude the poor [1]. Most informal settlement dwellers are squatters who have created homes on land over which they hold no legal rights. Informal settlements grow through both urban migration from rural areas and through displacement of people due to gentrification [2], development or conservation.

\subsection{Informal Settlements - Environmental Impacts and Issues}

Common themes of informal settlements include: inadequate sanitation systems, lack of access to clean water, poor structural quality of housing, poorly developed or even absent infrastructure, overcrowding, lack of social investment and infrastructure, insecure tenure and illegal subdivision [2]. The environmental challenges of informal settlements around the world can generally be summarised into the following:

Rapid urbanisation and migration by the rural poor - Informal settlements are characterised by rapid growth and settlement by the poor for whom proximity to work opportunities over-rides the hazards of settling on marginal land [3]. These areas are often the only largescale, viable solution to housing the poor [4]. Xalapa City in Veracruz, Mexico, is a typical example of a rapidly expanding informal settlement. Between the 1960 and 1980, the population of Xalapa increased by $300 \%$ to more than 200,000. It then doubled again from 1980 as people migrated from rural areas in search of work. The resulting environmental impacts were catastrophic with $90 \%$ of the land being altered [4].

The role of waterways as both sewage disposal system and potable water supply - Waterways in informal settlements often comprise both the only source of drinking water and the local sewage system [5]. If sanitation systems do exist, they are likely to be shared and substandard. There are several barriers to the implementation of sanitation systems in informal settlements, predominantly the unsuitability of land, high settlement densities, poor status of housing and lack of proximity to existing sewage networks [6]. In an Indonesian study [7], it was found that proximity to a river significantly influenced household behaviour, with those most reliant on the river also being the most at risk. In the Kambi Moto informal settlement in Nairobi, there is no freshwater even though a river runs directly through the settlement [8]. The river is so polluted through its use as a sewage system that the water cannot be used for any other purpose.

Rubbish disposal and the lack of waste management services - Rubbish is often disposed of in waterways and along roadsides of informal settlements due to a lack of formalised waste management systems and infrastructure. Any runoff interceded by areas of organic waste become nutrient laden - adding to existing water quality problems in waterways. In a study on informal settlements in Lagos, Nigeria, it was found that so much solid waste was being 
generated that government authorities did not have the capacity to address the issue without help from the private sector [9]. However, poorly maintained roads and infrastructure, as well as a lack of community education means that waste continues to pile up in waterways and long roads.

The implications of erosion, run-off and drainage in unsealed settlements - Street paving and civil drainage systems are either absent or in very poor structural condition in informal settlements. In many European informal settlements, rubbish is disposed of in the streets with leachate affecting nearby waterways. In the absence of development regulations, rapid construction using substandard materials results in sediment-laden run-off entering rivers and lakes [10]. Without site drainage infrastructure and appropriate treatment, rain events cause massive environmental problems and exacerbate ongoing water quality issues.

\subsection{Hue Informal Settlement}

Hue Citadel - Hue Citadel is the former imperial capital of Vietnam. Until 1777, Vietnam was divided into a southern section under the control of the Nguyen clan, and a northern section under the control of the Trinh clan. Following unification, Nguyen Anh became the first King of the Nguyen dynasty [11]. The Nguyen dynasty collapsed in 1945 and the capital was subsequently moved to Hanoi. Hue is now recognised as one of the best-preserved historic cities in Vietnam, comprising the capital city itself, the royal palace, temples, pagodas, mausoleums, churches, bridges and numerous relics laid-out over a large area [12]. Hue Citadel was designed around the principles of Feng Shui. The Citadel is surrounded by a system of moats referred to as Ho giam thanh, which are approximately $7 \mathrm{~km}$ in length and contain 10 gates. The moats are connected to the hydrological regime of the Huong River (the Perfume River). The main street layout in the Citadel has not significantly changed since historical times, with the exception of the western portion of the Citadel where the French constructed a military airport during the French occupation [11].

In 1993, the Complex of Hue Monuments was recognised by UNESCO and given World Heritage status under criteria iii and iv of the World Heritage Convention [12]. Following recognition by UNESCO, tourism numbers at Hue Citadel increased dramatically, coinciding with a spike in tourism to Vietnam following the implementation of Vietnam's 1986 Doi Moi economic liberalisation policy. By the year 2000, tourism visitation at Hue reached 470,000, which included 195,000 international tourists. By 2013, tourism had increased to 2,600,000, generating over 117 million USD in revenue [13].

Hue Citadel Informal Settlement - Around the world, informal settlements are as culturally and socially unique as the people and communities that inhabit them. This is true for Vietnam; however, there are also other layers of complexity which are unique to the country. Informal settlements in Vietnam need to be considered through the lens of the sociopolitical landscape of the past 50 years. Following the American War in Vietnam, 70\% of the population lived below the poverty line [14]. Combined with internal issues and post-war embargos, there was widespread poverty across the country. Vietnam's economic situation improved following the introduction of Doi Moi and the resulting growth of an emerging market economy and capitalism; however, this also led to a social and economic division of the population. Urban development in Vietnam is now in a transitional state subject to both state-controlled and market-driven forces. People with a higher social status and income are better placed to access new housing markets, whilst poorer people and communities remain excluded [14,15]. This widening socio-economic gap is one of the reasons why informal 
settlements in Vietnam continue to flourish [15]. Doi Moi triggered a process whereby housing improvements became common, with the upgrade of 'temporary' housing structures using recycled materials sourced for free [14]. Despite these improvements, housing in Vietnamese informal settlements remains structurally below standard and subject to natural hazards. Further, authorities are not willing to invest in the improvement of housing structures that they consider to be illegal [14].

During the American War in Vietnam, Hue was situated just $75 \mathrm{~km}$ south of the demilitarised zone and was the location of the 1968 Tet Offensive [16], in which thousands of civilians were killed during the United States and South Vietnamese's attempt to reclaim the city. During this time, hundreds of people escaped behind the rampart walls of the Citadel in search of shelter and protection. There are four types of streets within the Imperial Capital: alleyways, residential streets, shopping streets and open streets [11]. Alleyways increased in number following the influx of settlers during the war, with narrow alleyways being established to account for the high density of residents. Houses along alleyways and streets now tend to have space for shops and stalls, with smaller living areas located to the rear. There also tend to be small, protected areas used for communal outdoor living at the front of each property.

The Citadel is surrounded by heritage-listed walls. In places, these walls are $20-50 \mathrm{~m}$ wide and have been adapted and used for housing and farming by the informal settlement residents since the 1940s [17]. Fruit, vegetables and other produce grown in soil and sediment on these walls - and in the silted-up moats and canals of the waterways - are sold directly to nearby city dwellers [17]. As a result of UNESCO's current approach to world heritage site management, informal settlement dwellers on and around the walls are now destined for forced relocation.

\subsection{Environmental Issues in Vietnam}

Despite recent progress, there is still a great deal of work that needs to be undertaken to understand the complexity of broader environmental issues in Vietnam [18]. In general, these issues can be discussed under the following headings:

Water resources and site contamination - water is a central component of the Vietnamese landscape, culture and livelihood. There are significant problems with water pollution and public health, however, as economic development projects are constructed in the absence of adequate environmental impact assessment. In Hanoi for example, uncontrolled development growth has led to the discharge of domestic and industrial wastewater directly into the To Lich River, reducing it to an open sewer. Water quality has now deteriorated as far as $60 \mathrm{~km}$ downstream from Hanoi [18]. There are also significant levels of arsenic pollution in groundwater, with human hair samples in some delta regions in Vietnam showing high contamination levels [18].

In 2011, the World Health Organisation reported that only 105 of the 260 industrial parks in the country had wastewater treatment systems. The remainder were pumping industrial waste directly into waterways [19]. Hundreds of thousands of smaller industrial sites around Vietnam have no treatment facilities at all. From a domestic wastewater perspective, only $10 \%$ of wastewater was treated in 2011 , with the remainder discharged directly into waterways [19].

Water supply - Currently, only $60 \%$ of households in Vietnam are connected to a central water supply system; and even if connected, $40 \%$ of water is typically lost through leaky pipes [19]. 
Agent Orange - Seventy-seven million litres of Agent Orange defoliant and other chlorinated dioxin chemicals were sprayed over at least one-fifth of Vietnam during the American war. The American government stopped spraying in 1971, but the environmental impacts and human health implications of this program are still widely unknown [18].

Marine resources and water pollution - The direct disposal of wastewater into waterways has destroyed fisheries and resulted in outbreaks of cholera and other diseases [19]. Vietnam is one of the largest shrimp-producing countries in the world and this industry has resulted in high salinity levels of surface water, groundwater and soils. In fact, some inland surface water bodies now have higher salinity levels than seawater [18].

Air quality issues - Many of the larger cities in Vietnam are affected by severe air quality issues associated with urban traffic congestion, air pollution from unregulated industrial land use, unlicensed and unregulated brick-kiln emissions and fires [18].

Other environmental issues - Deforestation, biodiversity loss, climate change and unsustainable energy supply are becoming key environmental challenges in Vietnam [18].

\subsection{Environmental Impact Assessment in Vietnam}

Until recent times, Vietnam's growth and development was undertaken without consideration of the natural or social environment [20]. Following the implementation of the Convention on Biological Diversity in 1993, Vietnam was obliged to assess projects that may impact upon biodiversity. This was done through the enactment of the first Law on Environmental Protection 1993 (LEP 1993) [21]. The LEP 1993 set a broad regulatory framework for assessing the potential impacts of projects on a range of environmental issues. Fifteen years ago, the LEP 1993 underwent a significant review which culminated in the Law on Environmental Protection (Revised) 2005 (the LEP 2005) [20]. Despite several improvements, there was still a considerable gap between the theory and practice of EIA in Vietnam. An analysis of Vietnamese EIA policy and practice undertaken in 2011 concluded the following [20]:

- EIA was undertaken too late in the planning process.

- EIA was seen more as a 'means to an end'; rather than as an effective planning tool.

- There was a limited capacity to undertake effective EIA in Vietnam.

- There was a limited capacity for regulators to make independent decisions.

- The LEP 2005 was too prescriptive in terms of defining projects requiring EIA.

- EIAs lacked focus on environmental management and mitigation.

- Whilst the LEP 2005 included provisions for community engagement, these were discretionary and restrictive; particularly when undertaken for projects affecting poorer communities. Public involvement was often simply limited to the notification of a final decision.

- Monitoring and compliance with EIA conditions was extremely poor.

- Complications often arose from the involvement of international development organisations, who required higher levels of effectiveness for EIA's [20].

In 2014, the LEP was reviewed again, with the resultant Law on Environmental Protection 2014 (LEP 2014) providing a significant improvement in the identification of the types of projects that require EIA, the assessment processes for biodiversity impacts, the incorporation of assessment processes for human health impacts and the inclusion of a certification system for EIA practitioners [22] Despite this though, the broader challenges of Vietnamese EIA discussed above still remain; the most significant being that EIA is used only for defined types of projects and is limited in its requirement for local community consultation. 


\section{CONTEXT - LIVING HERITAGE? OR RELOCATION FOR CONSERVATION?}

There are several ways in which environmental and social issues can be resolved at informal settlements. The least preferable is through forced relocation. Around the world, 15 million people get displaced every year by development projects [1]. Increasingly, this includes people who have been forced to move due to conservation purposes. Examples of this include Cappadocia in Turkey, which was declared a World Heritage site in 1985. Following the heritage declaration, there has been a steady increase in tourists and a progressively challenging relationship with the local Islamic community who have been displaced from their traditional stone and cave houses in the conservation zone [23].

In Yinhuwan Village at Mount Sanqingshan and the Ancient City of Ping Yao in Shanxi Province (both in China) local communities were forced off their lands to make way for tourists. Access restrictions were then enforced through expensive ticketing for admission and residents could no longer afford to visit their own city [24,25]. Many of these areas have been subsequently studied by sociologists and anthropologists who have found that forced relocation has detrimental effects on social cohesion, mental health, livelihood and general wellbeing [26]. Comprehensive socio-economic surveys to gain an understanding of community social and economic networks in these areas are hardly ever undertaken. Various forms of capital are not investigated or assessed and residents' views and concerns are disregarded. Local capacity building is rarely undertaken and post-settlement monitoring is not considered. This is particularly the case for communities where land tenure is not recognised by authorities.

Heritage protection in Vietnam is considered by the government only in terms of how it relates to economic development [27]. In 1993, the Complex of Hue Monuments was given World Heritage status, and suddenly, people who had been living in the informal settlement at the Citadel all their lives were now considered, for all intents and purposes, as illegal squatters. Following the declaration, the government set about implementing a resettlement plan [28]. Due to early difficulties in the first relocation phase, the Hue government established a staged 'restoration and preservation plan' that would see nearly 180 households resettled at Huong So (several kilometres from their current dwellings) within five, four-floored apartments. The issues with this relocation program, however, demonstrate the importance of baseline socio-economic surveys to the success of relocation programs. In Hue Citadel, people live very connectedly between the indoor space, the outdoor space, their gardens and their work place. The new location is a multi-storey apartment; there is no room for farming or social interaction. The new apartments do not have space for running a business and they are a long way from schools and work. Finally, home improvement opportunities are now too expensive and neighbours that have lived together for generations are now separated.

All land from which people have been removed is eventually intended to be cleared [29]; however, it has been observed that as people are relocated and dwellings cleared, previous residents are either selling their new property and moving back to the Citadel, or new residents take their place [17]. Despite this, it is intended that eventually, all 700 households in the informal settlement will be relocated with the intent of preserving the architectural integrity of the site and enhancing tourism potential [30]. But what of the void left by the people that have been moved on? What affect will this forced relocation have on the cultural heritage that has been left behind? Devoid of community life; will the Citadel be more, or less, attractive to tourists? 


\section{ADAPTING ENVIRONMENTAL IMPACT ASSESSMENT FOR INFORMAL SETTLEMENTS}

EIA is widely accepted as the most effective tool for assessing the environmental issues associated with project proposals. It is generally required for two purposes: to systematically asses the impacts of a project, and to facilitate stakeholder engagement with the project [31]. Given the right statutory and policy environment, EIA provides a prescriptive pathway for clearly defining, assessing and mitigating environmental impacts. Formal EIA though is not always practical. The various challenges associated with implementing EIA for projects in developing countries has been investigated previously [20,21,32]; however, EIA in informal settlements poses another level of complication which can be exacerbated by illiteracy, high population densities, lack of funding, a lack of enforcement of statutory frameworks, complex and inter-related environmental and social issues, and a tendency for the impacted community to lack both adequate education as well as the confidence required to voice opinions [32].

Despite EIA's main aim being to specifically assess the impacts of individual projects; the objectives and practice of EIA can also be used to assess the impacts of broader schemes and situations - such as those presented by informal settlements. EIA in this context though must be adapted to suit the purpose, and to do this it is necessary to look to more efficient, streamlined or outcome-oriented forms of EIA. These forms of adaptive EIA are particularly useful for implementation in jurisdictions where proposals and projects may not legally require EIA; but where there is a risk of significant environmental impacts.

Rapid Environmental Assessment (REA) is a tool used in many countries to identify and prioritise environmental impacts and issues following a disaster event [33-35]. It is used to survey the environmental conditions of a location during a limited and specified period of time $[34,35]$. REA differs from EIA in that numerous technical specialists are not needed to rigorously and quantifiably assess all impacts; rather, professional environmental personnel can assess environmental factors from a qualitative perspective with the aim of identifying and prioritising environmental actions and investment. REA does not necessarily replace EIA; it simply fills a gap until such time that an EIA can be undertaken. Rapid EIA $[33,35]$ generally requires a process of:

- Compiling as much baseline data as possible in whatever limited timeframe has been applied to the study.

- Analysing, summarising and prioritising environmental issues of concern.

- Identifying the prioritised environmental impacts that require action.

- Identifying those issues that require further investigation by more specialised technical experts $[33,35]$.

Based on this, it is considered that this type of streamlined process could easily be adapted from assessing and prioritising issues in a disaster situation to assessing and prioritising environmental issues at informal settlements.

\section{APPLICATION IN PRACTICE - HUE CITADEL INFORMAL SETTLEMENT}

\subsection{Study Approach}

Environmental information and data in Hue is difficult to obtain. There is a general lack of research, the outcomes of EIAs are often not publicly released, and there are no consistent, long-term monitoring programs being undertaken by government agencies or international 
investment and aid agencies. Any EIA processes in this context must therefore out of necessity, return to grassroots levels. The basic principles of environmental knowledge must be applied and baseline assumptions must be made. To assess the environmental issues and impacts present at the Citadel informal settlement within the short timeframe, and following the philosophy of rapid EIA, the following approach was undertaken.

1. To understand the conflicting environmental issues and impacts, a literature review was undertaken focussing on Hue Citadel, informal settlements, world heritage, EIA and potential environmental improvement opportunities. The literature review was restricted to published journal papers, conference papers and published government reports and policy documents over the past twenty years (with one or two exceptions).

2. Four sets of environmental observations of the project area were made during a study trip to the site in June 2017. The quality of infrastructure and housing were noted; environmental behaviours were observed and recorded, and environmental conditions and notable impacts were assessed.

3. Finally, a community survey was prepared. Twenty-two informal settlement households along the heritage-listed rampart walls participated. Half of the households were in the south-eastern section of the Citadel (Thuan Thanh) and half were in the north-western section (Tay Loc). Twenty-seven questions were presented to the 22 survey participant households. Surveys were conducted in participants' homes. The first set of questions requested background demographic information; such as gender, age, employment status, employment location and household size. The second set of questions were related to values and were asked to gain information about residents' choices and priorities. Examples of these questions included the importance of issues such as remaining living in the citadel, access to clean water, toilets and rubbish bins and having space for animals and horticulture. Finally, several direct questions were asked relating to available services, infrastructure and environmental behaviours. Examples of these sorts of questions included whether participants' houses had a private drinking tap or a shared drinking tap. Likewise, whether they had a flush toilet or a shared street toilet. Other questions were related to rubbish disposal, flood damage, farming activities, and how strongly people felt about remaining living in the Citadel. It should be noted that a response was not able to be obtained on three of the original questions relating to sanitation.

\subsection{Findings}

The findings of the community surveys are outlined in Table 1.

Table 1: Community survey outcomes.

\begin{tabular}{lllll}
\hline Survey questions & Total & North-west & South-east & Comments \\
\hline $\begin{array}{l}\text { Location in the Hue } \\
\text { Citadel }\end{array}$ & 22 & 11 & 11 & Even distribution \\
$\begin{array}{l}\text { Gender } \\
\text { Age }\end{array}$ & - & $5 \mathrm{M} 6 \mathrm{~F}$ & $6 \mathrm{M} \mathrm{5F}$ & Even distribution \\
$-18-30$ & 3 & 1 & 2 & $\begin{array}{l}\text { Less young people at home } \\
\text { during the week day }\end{array}$ \\
$-31-49$ & 7 & 3 & 4 & -
\end{tabular}


Table 1: (Continued)

\begin{tabular}{|c|c|c|c|c|}
\hline Survey questions & Total & North-west & South-east & Comments \\
\hline$-50+$ & 12 & 7 & 5 & $\begin{array}{l}\text { More 50+ residents at home } \\
\text { during the week day }\end{array}$ \\
\hline $\begin{array}{l}\text { Number of people in } \\
\text { household }\end{array}$ & - & $\begin{array}{l}4.5 \\
\text { (average) }\end{array}$ & $\begin{array}{l}6.1 \\
\text { (average) }\end{array}$ & $\begin{array}{l}\text { Higher occupancy levels in } \\
\text { south-east }\end{array}$ \\
\hline Employment status & 22 & $\begin{array}{l}7 \\
\text { employed }\end{array}$ & $\begin{array}{l}6 \\
\text { employed }\end{array}$ & - \\
\hline $\begin{array}{l}\text { Employment in } \\
\text { Citadel }\end{array}$ & - & 5 & 3 & $\begin{array}{l}\text { More people in north-west } \\
\text { were employed in the local } \\
\text { area }\end{array}$ \\
\hline $\begin{array}{l}\text { Clean drinking water } \\
\text { to property }\end{array}$ & 22 & 0 & 0 & $\begin{array}{l}\text { No clean drinking water taps } \\
\text { direct to properties }\end{array}$ \\
\hline Access to flush toilet & 22 & - & - & $\begin{array}{l}\text { Difficult to determine } \\
\text { through interviews. Likely no } \\
\text { facilities. }\end{array}$ \\
\hline Rubbish bin & - & Street bins & Street bins & $\begin{array}{l}\text { Approximately } 1 \text { bin every } \\
100 \mathrm{~m}\end{array}$ \\
\hline $\begin{array}{l}\text { Property previously } \\
\text { flooded }\end{array}$ & 22 & 10 & 4 & $\begin{array}{l}\text { Greater flood damage in the } \\
\text { north-west }\end{array}$ \\
\hline $\begin{array}{l}\text { Home agriculture } \\
\text { activities }\end{array}$ & 22 & 7 & 3 & $\begin{array}{l}\text { Likely due to larger plots in } \\
\text { the north-west }\end{array}$ \\
\hline $\begin{array}{l}\text { Family and friends in } \\
\text { local area }\end{array}$ & 22 & 11 & 11 & $\begin{array}{l}\text { Strong social capital in both } \\
\text { areas }\end{array}$ \\
\hline $\begin{array}{l}\text { Willingness to change } \\
\text { behaviour to improved } \\
\text { environmental } \\
\text { conditions }\end{array}$ & 22 & 11 & 11 & $\begin{array}{l}\text { All properties very willing } \\
\text { to improve their local } \\
\text { environment }\end{array}$ \\
\hline $\begin{array}{l}\text { Permanency or quality } \\
\text { of housing }\end{array}$ & 22 & $\begin{array}{l}10 \\
\text { constructed } \\
\text { of } \\
\text { permanent } \\
\text { structures }\end{array}$ & $\begin{array}{l}6 \\
\text { constructed } \\
\text { of } \\
\text { permanent } \\
\text { structures }\end{array}$ & $\begin{array}{l}\text { Larger dwellings noted in } \\
\text { North-West }\end{array}$ \\
\hline \multicolumn{5}{|c|}{ Importance ranked from 1 (not important) to 5 (very important) of } \\
\hline $\begin{array}{l}\text { —Clean drinking } \\
\text { water }\end{array}$ & - & 4 & 5 & $\begin{array}{l}\text { Slightly more important for } \\
\text { residents in houses with poor } \\
\text { structural quality }\end{array}$ \\
\hline $\begin{array}{l}\text { —Health of water } \\
\text { bodies }\end{array}$ & - & 5 & 3 & $\begin{array}{l}\text { More important for residents } \\
\text { with larger, more permanent } \\
\text { dwellings }\end{array}$ \\
\hline $\begin{array}{l}\text {-Rubbish and } \\
\text { recycling bins }\end{array}$ & - & 4 & 5 & $\begin{array}{l}\text { More important for areas with } \\
\text { smaller houses and greater } \\
\text { occupancy levels }\end{array}$ \\
\hline
\end{tabular}


Table 1: (Continued)

\begin{tabular}{|c|c|c|c|c|}
\hline Survey questions & Total & North-west & South-east & Comments \\
\hline $\begin{array}{l}\text {-Toilets and } \\
\text { sanitation }\end{array}$ & - & 4 & 5 & $\begin{array}{l}\text { More important for residences } \\
\text { that do not currently have access }\end{array}$ \\
\hline $\begin{array}{l}\text {-Reducing air pol- } \\
\text { lution }\end{array}$ & - & 4 & 4 & $\begin{array}{l}\text { Of equal importance for } \\
\text { health }\end{array}$ \\
\hline $\begin{array}{l}\text { —Having land for } \\
\text { vegetables }\end{array}$ & - & 4 & 3 & $\begin{array}{l}\text { Important for supporting cur- } \\
\text { rent agricultural activities }\end{array}$ \\
\hline $\begin{array}{l}\text { —Having land for } \\
\text { animals }\end{array}$ & - & 3 & 3 & $\begin{array}{l}\text { Of equal, but not highest, } \\
\text { importance }\end{array}$ \\
\hline $\begin{array}{l}\text {-Tourism and visi- } \\
\text { tors to the Citadel }\end{array}$ & - & 3 & 3 & $\begin{array}{l}\text { Of equal, but not highest, } \\
\text { importance }\end{array}$ \\
\hline $\begin{array}{l}\text {-To remain living in } \\
\text { the Citadel }\end{array}$ & - & 4 & 3 & $\begin{array}{l}\text { More important for people } \\
\text { who had invested in housing } \\
\text { improvements }\end{array}$ \\
\hline $\begin{array}{l}\text {-To move away from } \\
\text { the Citadel }\end{array}$ & - & 2 & 4 & $\begin{array}{l}\text { Less important for people } \\
\text { who had invested in housing } \\
\text { improvements }\end{array}$ \\
\hline
\end{tabular}

Despite the small sample size, some of the key findings from the collected data are:

- Dwellings in the north-west sector were generally larger, better-constructed and more permanent in nature, when compared to dwellings in the south-east sector.

- There were lower dwelling occupancy levels in the north-west sector and it was less densely populated.

- Properties in the north-west had a greater level of flood damage than properties in the south-east.

- Residents in the north-west indicated a stronger preference to remain living in their current location, when compared to residents in the south-east. This is potentially because they had invested more time and money in their property, despite having no legal tenure. In the south-east sector, the poorer the quality of the housing structure - the greater the desire to relocate. Although the south-eastern sector residents as a whole still wanted to remain living in the local area.

- Residents often would not directly talk about whether a toilet was in or near their property; however, it was assumed through general conversations that there was no plumbing to individual properties.

- Access to clean drinking water was rated as being very important for residents - although there is currently a lack of access to clean water.

- Rubbish disposal and the provision of bins were very important for all respondents, although current facilities and services were inadequate. It was found through discussions with respondents that rubbish bins were provided on the streets at a rate of about 1 bin every $100 \mathrm{~m}$. However, in the south-east, $100 \mathrm{~m}$ equates to more than 20 households, which could in turn equate to more than 120 people. Waste was therefore disposed of in the streets and into waterways, not because people wanted to, but because they had to.

- All families said that they would be willing to learn to improve their local environment, particularly if it meant that they could remain in their current location. 
Following the analysed survey outcomes, literature review findings were then assessed in conjunction with observational data, as summarised below.

Water Quality Findings - Visual inspections of the Citadel noted significant eutrophication in waterways indicating high nutrient (particularly nitrogen and phosphorus) levels. High levels of single species macro-phytic growth in some lakes - and absolutely no aquatic vegetation growth in other lakes - demonstrates the generally unhealthy state of the waterways. Waterways were stagnant with low turbidity and likely low dissolved oxygen levels. Algal blooms were noted to reform very quickly after rain events. Species of Cyprinidae family (i.e. carp) were observed in many of the waterways.

Water is abundant in Hue - but water quality in the Citadel is very poor. Water supply for the formal areas of Hue is managed by the Hue Water Company (Hue WACO). The government plans to progressively construct water treatment plants for these areas of the City [30]. Faecal coliform levels are used as an indicator of faecal contamination in the environment. In a study investigating faecal coliform levels in four of the Citadel lakes, TinhTam, CayMung, TanMieu and HoVe, all lakes returned high faecal coliform contamination levels (between $780 \mathrm{MPN} / 100 \mathrm{~mL}$ and 4,050 MPN/100 mL) especially in the wet season [29]. In addition to faecal coliforms, E. coli and COD measurements were also found to exceed regulations at all monitoring points in the same lakes [18]. Water quality of the four lakes did not meet Vietnamese water quality standards [18].

In 2016 analysis of phosphorus flow in the Citadel, one hundred households were interviewed to investigate domestic waste and wastewater management issues [36]. A phosphorus flow model quantified phosphorus input and output and results showed that all wastewater from the Citadel discharged directly into water bodies and groundwater. Untreated sewage, and to a lesser extent fertiliser use, was found to be the largest source of phosphorus loading. Phosphorus levels were found to be significantly higher in the Citadel than at other monitoring points in Vietnam (41.2 kg P/ha year) [20]. These high phosphorus levels have resulted in the eutrophication of all waterways. Domestic wastewater is not collected or treated in Hue [30]. Wastewater flows directly to the Hoang (Perfume) River and the lakes and canal of the Citadel. The Hue Environmental Protection Company (HEPCO) manages the City's domestic wastewater system and with the Japan International Cooperation Agency is currently developing a domestic wastewater collection network and treatment plant on the banks of the Perfume River [30].

It has been reported that $100 \%$ of Hue city is linked via the city's water mains to a clean water supply [37]. However, these statistics do not include the informal settlements of the Citadel walls [37]. Likewise, in 2011, whilst $87 \%$ of Hue's population had access to a toilet with a septic tank system, $2 \%$ did not have access to a toilet at all, including many residents living in informal settlements along the Citadel rampart walls [37]. This is reflected in available data from the Provincial Centre for Preventative Medicine 2011 [37], which reports on sanitation services available at a range of wards across Hue. Lieu [37] reports specifically on conditions from an informal settlement at Phu Binh ward, which is located directly adjacent to the canal and northern walls of the Hue Citadel. Within this ward, there is a population of 783 people living in 115 households and only 12 available toilets [37].

Flooding, Inundation and Siltation Findings - Canals and waterways were observed to be excessively silted with subsequent low or absent water flows. There appeared to be limited drainage capacity which would contribute to inundation during rainfall events. The physical characteristics of the interconnected water system have changed over recent years due to 
rapid urbanisation and lack of both infrastructure and environmental management, with the surface area of the lakes decreasing and narrowing. In fact, from 2003 to 2007, the total area of the lakes decreased by $18 \%$ [38]. Large-scale floods used to occur in Hue every 50 years, however since 1993 they are now occurring every 3 years [29]. This is a result of climate change impacts and excessive deforestation upstream of the Hoang River. Siltation is impacting upon the natural flows of the interconnected waterways. Siltation and sedimentation are primarily a result of construction without sediment or drainage control measures, construction within the floodplain, current low flows of water, sewage and waste accumulation and the general lack of appropriate infrastructure. Lakes are also being used for the farming of rau muống, further impeding flows.

Hue has one of the highest rainfalls in Vietnam (with an average of $900 \mathrm{~mm}$ in October; the wettest month of the year) $[11,12,37]$ and the threat of flood is ever present [11]. Major floods affected the citadel in 1953, 1985 and 1999, destroying a number of historical monuments and dwellings. Traditionally, the interconnected series of moats, canals and lakes in the Citadel helped to regulate flows and mitigate flood impacts. At present, however, the waterways are silted-up or completely blocked by a combination of sediment and waste, and the severity and consequence of floods is becoming more intense. Dredging now must be undertaken to help maintain minimum flows.

Waste Management Findings - During the community surveys, it was observed that the interior of all 22 of the individual informal settlement houses along the rampart walls in the Citadel appeared tidy and clean, but externally rubbish could be seen deposited in large piles along the streets and in waterways. Organic waste was observed to be in varying states of decomposition in waterways and was obviously contributing to significant eutrophication. Limited small-scale waste recycling occurs. Ninety-five percent of rubbish in the City of Hue is collected, transported and disposed of to landfill [30], although it is worth noting that there is no separate hazardous waste disposal site (such as for paints, chemicals and batteries) - all waste is disposed of to the same facility. In the wider city, more than $80 \%$ of the waste stream is comprised of organic food waste and $8 \%$ comprises plastic [37]. There is no regular waste collection at the Hue informal settlement [30].

Uncontrolled Development and Poor Environmental Planning Findings - Uncontrolled development, both within and around the Citadel is reducing the extent of land available for natural drainage and water retention. Developments are being built over water drainage channels, and water flows over hardstand areas and contributes to existing flood issues. Traditional Vietnamese garden houses are being replaced with dense, inappropriate housing which have transformed the way that water is absorbed into the ground.

Air Quality Findings - Observations of activities that could contribute to a reduction in the air quality in the Citadel were found to include unsealed roads, open fires, waste incineration, construction activities, unprotected stockpiles and motorbikes. The concentration of suspended particulates, sulphur dioxide and carbon dioxide is high in industrial areas and along roadsides [30]. Urban air quality is generally low due to industrial emissions.

Informal Land Use Findings - Informal horticultural practices were observed both within the silted-up waterways around the Citadel, and on the actual heritage-listed rampart walls. Vegetables (such as rau muống water spinach), herbs and spices, fruit and grain were all observed, as well as chickens, pigs and aquaculture. Animal feed, waste and fertilisers were all assumed to be contributing to water quality issues via run-off. 


\subsection{Using Adaptive EIA for Community Improvement}

As discussed in Section 3, resettlement is often the preferred policy for addressing existing communities living in World Heritage areas. In the case of the Hue Citadel, this is despite Section 119 of the Operational Guidelines for the Implementation of the World Heritage Convention stating that: "World Heritage properties may support a variety of ongoing and proposed uses that are ecologically and culturally sustainable and which may contribute to the quality of life for the communities concerned", and "Communities should be supported in active participation of sustainable activities" [39]. A more inclusive and sustainable approach to world heritage conservation is clearly needed, one that would assess the value of the Citadel not only from a heritage viewpoint, but from a diverse perspective, considering its modern cultural values as well as its historical ones [20].

Informal settlements cause significant financial impacts in the form of the environmental problems that they cause and the resulting human health costs [40]. These impacts result from challenges such as the lack of paved roads, clean piped water, sanitation and waste collection and disposal. When these costs are considered, informal settlements may be no less expensive than formalised development [40]. In a study of informal settlements in Montego Bay, Jamaica, it was found that road coverage within informal settlements increased significantly with the formality of the settlement, and the more formalised the development; the less of an impact it had on the receiving environment and on the crucial tourism trade [40]. Following on from this context, it would be beneficial to similarly attempt to determine whether there is a direct link between the level of formalisation of development within the Hue Citadel informal settlement; and the condition of the receiving environment. For example, one of the early findings of the current study was that the north-west section of the informal settlement had more permanent and formalised development than the south-east section. Does this correspond with the condition of the receiving environment in both sectors of the informal settlement? Is water quality in the canals, moats and lakes any worse in the southeast section of the Citadel than the north-west section? Are water bodies more eutrophic in the south-east, and are problems with rubbish disposal more apparent and is sedimentation worse? Unfortunately, this was outside the scope of the current study due to a number of limitations. An attempt was made to review potential correlations between the location of households surveyed in the current study and data collection locations in published literature, i.e. $[5,11,29,36,38])$, however no firm associations could be made from a geographical perspective.

Nevertheless, if the receiving environment was determined to be more polluted in the south-east section of the informal settlement (where more properties were classed as being constructed from temporary structures and there was a higher population density), than the north-west section (where the majority of dwellings were permanent and where there was a lower population density) then a further justification could be made for improving the environmental conditions of the environment by upgrading the informal settlement, as opposed to relocating the community outside of the of the Citadel.

In determining whether an informal settlement improvement plan could result in a healthier environment, it is important to first prepare an inventory of all infrastructure and environmental and civil improvement initiatives that are currently earmarked for development in the City. During the literature review undertaken for this paper, several studies and strategies were identified that list infrastructure projects and proposals currently either being planned or constructed in Hue [5,13,29,30,36,38]. Examples include: 
- The construction of a wastewater treatment plant, pump stations and pipelines.

- River, moat, canal and lake dredging and rehabilitation projects to restore traditional water flows.

- Bank stability, drainage improvement and pavement works.

- Restoration works to the water channels, flood gates and original roadways.

- Development of additional landfill facilities.

These projects are crucial for addressing the city's environmental problems. They are, however, all being undertaken with total disregard to the informal settlement. For the informal settlement community to have any chance of remaining in their homes, it would require environmental behavioural change and this could only be achieved through the preparation of an Environmental Improvement Plan that has been prepared in conjunction with existing management and policy plans, including the UNESCO World Heritage values, the Complex of Hue Monuments Management Plan, the Hue Green City Action Plan, Thua-Thien-Hue Province strategic plans, environmental and development legislation and recognition that heritage protection cannot be undertaken in isolation, that the needs of existing communities should be considered and valued.

It is envisaged that a broad approach to environmental improvement could commence with the development of a Pilot Environmental Improvement Plan, which would incorporate:

- An assessment of all proposed infrastructure improvement projects in Hue and investigate how they could be expanded to include the informal settlement.

- A more detailed environmental impact assessment of the informal settlement.

- Set environmental objectives to prioritise environmental challenges, to increase awareness and train the community in improved environmental practices.

- Include socio-economic surveys to understand sources of capital.

- Develop prioritised actions for each issue with the local community.

- Outline implementation procedures, timeframes and funding sources.

- Monitor success through the development of appropriate indicators and reporting.

Aside from infrastructure projects which, with adequate funding, could be extended to the Citadel, the Environmental Improvement Plan should include a number of goals and actions (Table 2).

For every goal identified in the Environmental Improvement Plan, there would need to be associated actions, tasks, timing, benefits, funding opportunities and environmental indicators developed [41]. Individual tasks would delineate those on-ground activities that could be achieved with the right funding and timing.

Following the site observations and community surveys undertaken for this project in June 2017, a draft Environmental Improvement Plan was developed based upon the above goals and actions. In all, more than 70 tasks and 60 key indicators were developed as part of the plan. Any plan developed would need to be done in partnership with the Hue informal settlement residents. It would need to be straightforward, easily accessible and achievable. It would need to be a plan that was owned and enforced by the community and prepared in conjunction with infrastructure upgrades and environmental awareness training. It is understood, of course, that a plan such as this is idealistic, and at this stage, purely an academic exercise. It is also understood that many of the actions listed in the plan are counter-productive to the objectives of the local authorities, as a challenge that is consistent across the world's informal settlements is that of 'recognition of tenure'; once you start providing infrastructure and services to an informal settlement; you are essentially recognising the rights of the people that live there. 
Table 2: Hue Citadel informal settlement environmental improvement plan - goals and actions.

\begin{tabular}{|c|c|}
\hline Goals & Actions \\
\hline \multirow{2}{*}{$\begin{array}{l}\text { 1. To improve waste } \\
\text { management practices }\end{array}$} & Ensure that all rubbish is disposed of in rubbish bins \\
\hline & $\begin{array}{l}\text { Ensure rubbish and general waste does not enter } \\
\text { waterways }\end{array}$ \\
\hline $\begin{array}{l}\text { 2. To improve rates of waste } \\
\text { recovery and recycling }\end{array}$ & $\begin{array}{l}\text { To implement waste separation techniques and } \\
\text { facilities throughout the community }\end{array}$ \\
\hline \multirow{2}{*}{$\begin{array}{l}\text { 3. To reduce hazardous waste } \\
\text { disposal in waterways and } \\
\text { public places }\end{array}$} & $\begin{array}{l}\text { Ensure all hazardous waste is collected and disposed of } \\
\text { appropriately }\end{array}$ \\
\hline & $\begin{array}{l}\text { Lobby local authorities for establishment of a secure } \\
\text { hazardous waste disposal facility or site }\end{array}$ \\
\hline \multirow{7}{*}{$\begin{array}{l}\text { 4. To improve the water quality } \\
\text { of the lakes and canals }\end{array}$} & Protect surface water sources from wastewater \\
\hline & Protect surface water sources from rubbish disposal \\
\hline & Protect surface water sources from sedimentation \\
\hline & Protect surface water sources from contamination \\
\hline & $\begin{array}{l}\text { Educate the community about water quality issues and } \\
\text { the impacts of local actions }\end{array}$ \\
\hline & Introduce a comprehensive wastewater monitoring plan \\
\hline & Improve water quality monitoring \\
\hline $\begin{array}{l}\text { 5. To provide a clean water } \\
\text { supply }\end{array}$ & Provide clean potable water to all residential properties \\
\hline \multirow[t]{2}{*}{$\begin{array}{l}\text { 6. To improve local air quality } \\
\text { conditions }\end{array}$} & $\begin{array}{l}\text { Improve hardstand areas to reduce dust emissions } \\
\text { during dry periods }\end{array}$ \\
\hline & $\begin{array}{l}\text { Separate competing land uses to reduce harmful } \\
\text { emissions }\end{array}$ \\
\hline \multirow{2}{*}{$\begin{array}{l}\text { 7. To improve soil quality in the } \\
\text { catchment area of the lakes and } \\
\text { canals }\end{array}$} & $\begin{array}{l}\text { Promote sustainable land management practices in } \\
\text { small-scale agricultural plots }\end{array}$ \\
\hline & $\begin{array}{l}\text { Implement an education program for small-scale } \\
\text { holdings regarding sustainable land management } \\
\text { practices }\end{array}$ \\
\hline \multirow[t]{2}{*}{$\begin{array}{l}\text { 8. To secure and conserve } \\
\text { agricultural land }\end{array}$} & $\begin{array}{l}\text { Assess the level of productive agricultural land in the } \\
\text { informal settlement areas and prepare a zoning plan }\end{array}$ \\
\hline & $\begin{array}{l}\text { Secure the definition of agricultural land as a legitimate } \\
\text { land use type in the informal settlement }\end{array}$ \\
\hline \multirow[t]{2}{*}{$\begin{array}{l}\text { 9. To rehabilitate the lakes and } \\
\text { canals }\end{array}$} & $\begin{array}{l}\text { Improve water quality and natural flows in ponds and } \\
\text { canals }\end{array}$ \\
\hline & Improve the biodiversity of ponds and canals \\
\hline $\begin{array}{l}\text { 10. To educate the community } \\
\text { and improve environmental } \\
\text { behaviour }\end{array}$ & $\begin{array}{l}\text { Design and implement an environmental education } \\
\text { awareness program }\end{array}$ \\
\hline
\end{tabular}




\section{CONCUSIONS}

Assessing the environmental impacts of projects in 'developing' countries has many challenges: the lack of baseline information, the quality of data, inadequate environmental guidelines and a tendency to not share or publish outcomes. These challenges are complicated when an attempt is made to utilise EIA principles to assess the impacts of an informal settlement; and to then determine whether, with adequate mitigation; the informal settlement community could remain living in the area in which they have so much social, economic and cultural capital. Following on from the concept of 'living heritage' this paper has suggested that devoid of community life; the Hue Citadel World Heritage site would be less attractive to tourists. It alternatively suggests that following a process of adaptive EIA which has been targeted to an informal settlement context, and with a compilation of all existing infrastructure upgrade proposals; a plan could be prepared and implemented - in conjunction with local authorities, aid agencies and the community - which would help address the environmental challenges present at the site and allow the community to remain living in the Citadel.

\section{ACKNOWLEDGEMENTS}

The author would like to thank Dr Matthew Rofe, Khanh Tran, Ramin Moradi, Ben Andary, the University of South Australia and the Hue University of Sciences in Vietnam.

The author would also like to acknowledge that some sections of this study were presented at the Environmental Impact 2018 Wessex Institute Conference in Naples, Italy.

\section{REFERENCES}

[1] Pienaar, J M, Planning, informal settlement and housing in South Africa: the development facilitation act in view of Latin American and African developments. The Comparative and International Law Journal of South Africa, 35(1), pp. 1-25, 2002.

[2] Jiusto, S., Squatting: developing world. International Encyclopaedia of Housing and Home. Elsevier Ltd, London, 2012.

[3] Arcidiacono, A. Causone, F. Grosso, M. Masera, G.Tadi, M. \& Zadeh, H M., Environmental performance and social inclusion: a project for the Recinha Favela in Rio de Janeiro. Proceedings of the 9th International Conference on Sustainability in Energy and Buildings, SEB-17, 5-7 July 2017, Chania, Crete, Greece, pp. 356-365. 2017.

[4] Benitez, G. Perez-Vazquez, A. Nava-Tablada, M. Equihua, M. \& Alvarez-Palacios, J L., Urban expansion and the environmental effects of informal settlements on the outskirts of Xalapa City, Veracruz, Mexico. Environment and Urbanisation, 24(1), pp. 149-166, 2012.

[5] Nagano, Y. Teraguchi, T. Lieu, P K. \& Furumai, H., Characterisation of water pollution in drainage networks using continuous monitoring data in the citadel area of Hue City, Vietnam. Water Science and Technology, 70(4), pp. 612-619, 2014.

[6] Mels, A. Castellano, D. Braadbaart, O. Veenstra, S. Dijkstra, I. Beulman, B. Singels, A. \& Wilsenach, J A., Sanitation services for the informal settlements of Cape Town, South Africa. Desalination, 248, pp. 330-337, 2009.

[7] Vollmer, D. \& Gret-Regamey, A., Rivers as municipal infrastructure: demand for environmental services in informal settlements along an Indonesian River. Global Environmental Change, 23, pp. 1542-1555, 2013.

[8] Toomey, B., Slums of hope: land tenure reforms, local economic development and environmental improvement in a Kenyan Shanty Town. Local Economy, 25(3), pp. 234-239, 2010. 
[9] Opoko, A \& Oluwatayo, A., Private sector participation in domestic waste management in informal settlements in Lagos, Nigeria. Waste Management and Research, 34(12), pp. 1217-1223, 2016.

[10] Badyina, A. Potsiou, C. \& Tsenkova, S., Self-Made Cities: In Search of Sustainable Solutions for Informal Settlements in the United Nations Economic Commission for Europe Region, United Nations Publications, 2009.

[11] Nguyen Ngoc Tung. Pham Dang Nhat Thai. Tran Thanh Nhan \& Pham Manh Hung., Transformation of Hue Citadel, Vietnam. Proceedings of the 4th International Workshop Between Hue University of Sciences and University of South Australia. Hue 2017, pp. 10-19, 2017.

[12] Huynh Thi Anh Van., The complex of hue monuments and the management of natural disasters in response to climate change. Proceedings of the 4th International Workshop between Hue University of Sciences and University of South Australia. Hue 2017, pp. 20-28, 2017.

[13] Santikul, W. Pratt, S. Kuan, W I. Wong, C I. Chan, C C. Choi, W L \& Chong, O F., Impacts of tourism on the quality of life of local residents in Hue, Vietnam. Anatolia, 27(4), pp. 405-420, 2016.

[14] Chantry, G \&Norton, J., Social and economic inequality limits disaster prevention amongst the most vulnerable in Vietnam. Disaster Management and Prevention, 28(1), pp. 50-59.

[15] Minnery, J. Argo, T. Winarso, H. Hau, D. Veneracion, C Forbes, D \& Childs, I., Slum upgrading and urban governance: case studies in three South East Asian cities. Habitat International, 39, pp. 162-169.

[16] Willbanks, J., The Tet Offensive: A Concise History. Columbia University Press, 2007.

[17] Wood, K C., Displacement for conservation: one of the adverse impacts of cultural world heritage management in Hue, Vietnam. Heritage, Chapter 2: Heritage and Society, ed. Amoeda, R. Lira, S. \& Pinheiro, C, pp. 365-375, 2012.

[18] Nguyen, T T., Vietnam and the environment: problems and solutions. International Journal of Environmental Studies, 66(1), pp. 1-8, 2009.

[19] World Health Organisation, Vietnam. World Health Organisation \& AusAID. 2011.

[20] Clausen, A. Hoa Vu, H \& Pedrono M., An evaluation of the environmental impact assessment system in Vietnam: the gap between theory and practice. Environmental Impact Assessment Review, 31, pp. 136-143, 2011.

[21] Swangjang, K., Comparative review of EIA in the association of Southeast Asian nations. Environmental Impact Assessment Review, 72, pp. 33-42.

[22] Nghiem, H., Environmental impact assessment in Vietnam. www.aecen.org/sites/ default/files/05_presentation_on_eia_vietnam.pdf, 2015 (Accessed 16 July 2017).

[23] Tibet, E E. \& Kent, U., Development or displacement? Resettlement and adaptation among the cave dwellers in Cappadocia. Anthropology News, November 2010.

[24] Wang, S Y., From a living city to a World Heritage City: authorised heritage conservation and development and its impact on the local community. International Development Planning Review, 34(1), pp. 1-17, 2012.

[25] Su, M M. Wall, G \& Xu, K., Heritage tourism and livelihood sustainability of a resettled rural community: Mount sanqingshan world heritage site, China. Journal of Sustainable Tourism, 24(5), pp. 735-757, 2016.

[26] Brockington, D \& Igoe, J., Eviction for conservation: a global overview. Conservation and Society, 4(3), pp. 424-470, 2006. 
[27] Vu Thi Hong Hanh., Canal-Side Highway in Ho Chi Minh City (HCMC), Vietnam - issues of urban cultural conservation and tourism development. GeoJournal, 66, pp. 165-186. 2006.

[28] Hong Giang Nguyen \& Hoang Ngo Tu Do., Cultural heritage preservation case study of tasks of clearance and resettlement around hue citadel wall and concave areas. Proceedings of the 4th International Workshop Between Hue University of Sciences and University of South Australia: Hue 2017, pp. 10-19, 2017.

[29] Ky, N M. \& Lam, N H., Analysis of changing trend of faecal coliform levels at lakes in hue citadel, Vietnam. Environment and Natural Resources, 14(1), pp. 1-7, 2016.

[30] ADB, Hue Green City Action Plan. Asian Development Bank, Philippines, 2015.

[31] Shakib-Manesh, T E. Hirvonen, K O. Jalava, K J. Alander, T \& Kiotunen, M T., Ranking of small scale proposals for water system repair using the rapid impact assessment matrix (RIAM). Environmental Impact Assessment Review, 49, pp. 49-56. 2014.

[32] Hostovsky, C. MacLaren, V \& Mcgrath, G., The role of public involvement in environmental impact assessment in Vietnam: towards a more culturally sensitive approach. Journal of Environmental Planning and Management, 53(3), pp. 405-425.

[33] Kelly, C., Benfield Hazard Research Centre \& CARE International. Rapid Environmental Assessment (REA): basic concepts and methodology. Haiti Workshops on the Environmental Management of Small-Scale Development Programs. Sun Mountain International. 2008.

[34] Hauer, M., Guidelines for Rapid Environmental Impact Assessment in Disasters. US Agency for International Development. Version 5 - 2018.

[35] United Nations High Commissioner for Refugees. Framework for Assessing, Monitoring and Evaluating the Environment in Refugee-Related Operations: Module 3 Rapid Environmental Assessment. UNHCR. 2009.

[36] Anh, T N Q. Harada, H. Fujii, S. Anh, P N. Lieu, P K. \&Tanaka, S., Preliminary analysis of phosphorus flow in Hue Citadel. Water Science and Technology, 17(1), 2016.

[37] Lieu, P K., Current status of water-related sanitation conditions in Hue City, Vietnam. ICSS Asia, Indonesia. 2012.

[38] Lieu, P K. Giang, N B. \& Loc, D T T., Current status of physical and wastewaterreceiving characteristics of lakes and canal outside Hue Citadel. Sustainable Urban Regeneration, 8(March), pp. 18-20, 2011.

[39] UNESCO, Operational Guidelines for the Implementation of the World Heritage Convention. UNESCO, World Heritage Centre 2017.

[40] Ferguson, B., The environmental impacts and public costs of unguided informal settlement; the case of Montego Bay. Environment and Urbanisation, 8(2), pp. 171-194, 1996.

[41] Nixon, B., Environmental sustainability opportunities at informal settlements in UNESCO world heritage areas: the case study of Hue, Vietnam. WIT Transactions on Environmental Impact IV, WIT Press, 2018. 